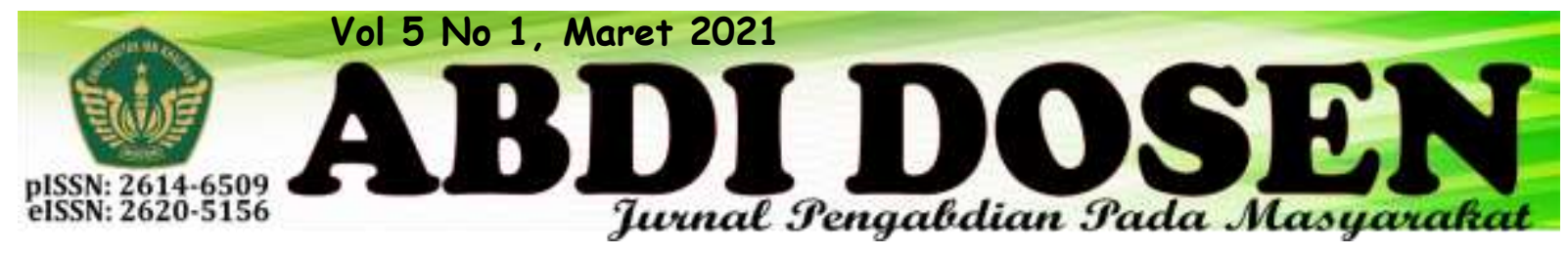

\title{
EDUKASI GENERASI Z (DIGITAL) DAN POLA KEHIDUPAN BARU MENGHADAPI MASA NEW NORMAL
}

\author{
Intan Kumalasari ${ }^{1}$, Maliha Amin ${ }^{2}$, Herawati Jaya ${ }^{3}$, Ratna Ningsih ${ }^{4}$ \\ zoominar123@gmail.com ${ }^{1}$ \\ malihaamin@poltekkespalembang.ac.id ${ }^{2}$ \\ herajaya@poltekkespalembang.ac.id ${ }^{3}$ \\ ratnaningsih@poltekkespalembang.ac.id ${ }^{4}$ \\ Politeknik Kesehatan Kementerian Kesehatan Palembang 1,2,3,4
}

\begin{abstract}
The government's decision to reopen schools and campuses after the Covid-19 pandemic requires readiness, especially for adolescents, who are mostly students. On the one hand, adolescents feel happy with the reopening of offline learning activities, but on the other hand there are fears and worries about their personal safety. Based on the analysis of the situation in the field of indecision faced by adolescents due to the lack of studies on the impact of the new normal if applied in Indonesia. In addition, the lack of outreach from the government on the policies that have been stipulated makes the public confused, so that their implementation is not appropriate. The purpose of this activity is to provide an understanding to adolescents about the new normal and preparations for the new normal. The method used in this activity is health education through online seminars. The results of this activity indicate that most of the adolescents are ready to face the new normal period and are ready to become agents of change for their peers. The results of this activity can also provide input for schools, campuses and managers to work hand in hand to prepare schools and campuses ready for the new normal by providing repeated understanding of new habits that must be adopted in the new normal period regularly so that schools and new campuses are normal. can be realized.
\end{abstract}

\section{Keywords : Education, Generation Z, New Normal}

\begin{abstract}
ABSTRAK
Keputusan pemerintah untuk membuka kembali sekolah dan kampus pasca pandemi covid-19 membutuhkan kesiapan khususnya bagi remaja yang sebagian besar adalah pelajar dan mahasiswa. Di satu sisi remaja merasa senang dengan dibukanya kembali kegiatan pembelajaran secara luring, namun disisi lain ada ketakutan dan kehawatiran remaja akan keselamatan diri. Berdasarkan analisis situasi dilapangan kebimbangan yang dihadapi remaja karena minimnya kajian tentang dampak new normal jika diterapkan di Indonesia. Selain itu, kurangnya sosialisasi dari pemerintah atas kebijakan yang ditetapkan membuat masyarakat bingung, sehingga pelaksanaannya menjadi tidak sesuai. Tujuan kegiatan ini adalah memberikan pemahaman kepada remaja tentang new normal dan persiapan-persiapan menghadapi new normal. Metode yang digunakan dalam kegiatan ini adalah pendidikan kesehatan melalui seminar daring. Hasil dari kegiatan ini menunjukkan sebagian besar remaja telah siap menghadapi masa new normal dan siap menjadi agen perubahan bagi sebayanya.
\end{abstract}


Hasil kegiatan ini juga dapat menjadikan masukan bagi pihak sekolah, kampus dan pengelola agar dapat bahu membahu mempersiapkan sekolah dan kampus siap new normal dengan memberikan pemahaman berulang tentang kebiasaan-kebiasan baru yang harus di adopsi di masa new normal secara berkala agar sekolah dan kampus new normal dapat terealisasi.

\section{Kata Kunci : Edukasi, Generasi Z, New Normal}

\section{PENDAHULUAN}

Menghadapi wabah pandemic Covid19 hampir di seluruh negara memberlakukan kebijakan lockdown (PSBB), pembatasan sosial, work from home dan learn from home. Langkah inipun diambil oleh pemerintah Indonesia untuk menekan laju penyebaran virus corona. Kebijakan ini tentu berdampak diberbagai sektor baik politik, ekonomi, social, budaya maupun pertahanan dan keamanan. Namun setelah beberapa bulan kebijakan tersebut diambil sejumlah negara saat ini mulai melakukan pelonggaran pembatasan aktivitas sosial dan ekonomi secara bertahap. Kembali pada kehidupan normal setelah menjalani kebijakan pemerintah untuk bekerja, belajar, dan beribadah dari rumah pasca pandemi Covid-19, membutuhkan kesiapan khususnya bagi para remaja. karena telah terjadi perubahan kebiasaan yang signifikan akibat kondisi ini. (Anggreni, S., 2020). Sehingga, diperlukan kesiapan baik secara fisik, mental, maupun sosial untuk dapat beradaptasi kembali dengan kebiasaan-kebiasaan sebelum pandemi, selain itu, kebijakan untuk memasuki era new normal bukan berarti bebas untuk melakukan segala aktivitas tanpa ada batasan melainkan ada beberapa hal yang perlu untuk diperhatikan.

Menurut The Generation Guide (2015), Generasi $\mathrm{Z}$ atau yang sering disebut sebagai generasi Post-Milenial atau information Generation (iGeneration) adalah remaja yang lahir di awal tahun 1995-2000an sehingga diperkirakan usia mereka sekarang rata-rata berada di rentang 11-24 tahun. Salah satu karakteristik yang paling khas dari generasi $\mathrm{Z}$ adalah sangat peka terhadap teknologi, internet, dan media sosial. Generasi Z merupakan sumber daya potensial Indonesia dimasa yang akan datang karena merupakan modal pembangunan yang sangat besar bagi masa depan Indonesia. Bila merujuk pada definisi remaja menurut BKKBN ( (2011) yaitu mereka yang berada di rentang usia 10-24 tahun, maka saat ini mayoritas remaja Indonesia merupakan generasi Z.

Menurut Badan pusat statistik (BPS, 2019), jumlah generasi $Z$ di Indonesia mencapai 64,19 Juta jiwa dan 66,23\% nya adalah pelajar dan mahasiswa. Dengan diberlakukannya kebijakan new normal. maka sebagian besar remaja yang merupakan pelajar dan mahasiswa akan mempersiapkan diri untuk kembali melanjutkan aktivitas utamanya yaitu sekolah dan kuliah, Bagi pelajar dan mahasiswa, penerapan new normal bisa jadi harapan baru dimana pelajar dan mahasiswa yang selama ini tidak nyaman dengan pembelajaran dan perkuliahan daring dapat kembali merasakan kehidupan sekolah dan kampus seperti sedia kala, namun bila keinginan untuk kembali ke sekolah dan kampus tidak dipersiapkan secara serius, dan tidak didukung dengan kondisi di lapangan, maka remaja akan menjadi penyumbang jumlah masyarakat 
yang masif yang bisa membawa virus paling efektif.

Meskipun hasil penelitian Davies, N.G., et.al. (2020) menunjukkan bahwa remaja atau orang yang berusia di bawah 20 tahun memiliki risiko lebih rendah 50 persen atau setengah kali lebih kecil dibanding orang yang berusia di atas 20 tahun untuk terinfeksi virus corona (Covid19), namun faktanya, kondisi di lapangan menunjukkan semakin meningkatnya kasus terkonfirmasi positif covid-19 yang membuat remaja takut dan cemas untuk kembali ke sekolah ataupun ke kampus karena berisiko meningkatkan penularan secara drastis, artinya kondisi ini belum aman bagi pelajar maupun mahasiswa. Banyak terjadi penambahan kasus baru di beberapa negara setelah mereka memberlakukan new normal, salah satunya dengan membuka kembali sekolah seperti di Korea Selatan dan Swedia (Apriliana, Y., 2020).

Berdasarkan analisis situasi yang dilakukan oleh tim terhadap 40 mahasiswa melalui google form dapat diketahui bahwa $27,4 \%$ memiliki pemahaman yang baik tentang new normal. 21,1\% mengaku bimbang atas diberlakukannya new normal. Sedangkan $51,5 \%$ tidak siap atau merasa takut menghadapi new normal. Kebimbangan yang dihadapi mahasiswa tersebut karena minimnya kajian tentang dampak new normal jika diterapkan, selain itu, kurangnya sosialisasi dari pemerintah atas kebijakan yang ditetapkan membuat masyarakat bingung, sehingga pelaksanaannya menjadi tidak sesuai. Remaja yang siap dengan new normal karena merasa bosan dan mengalami tekanan psikologis saat di rumah saja. Hal tersebut diperkuat dengan publikasi thelancet.com yang berjudul Mental health effects of school closures during COVID-
19 oleh Lee, J (2020). Dalam publikasi tersebut dituliskan bahwa sekolah merupakan rutinitas yang penting bagi kaum muda untuk mengurangi masalah kesehatan mental. Ketika sekolah ditutup atau diganti dengan daring, maka kaum muda yang bersekolah ini kehilangan kebahagiaan dalam hidup yang mereka lalui karena pergi ke sekolah merupakan perjuangan bagi anak-anak yang memiliki kerapuhan mental. Hal senada disampaikan oleh Zanonia Chiu, seorang psikolog klinis anak dan orang dewasa di Hongkong yang menyatakan bahwa ketika sekolah ditutup sebagian dari kaum muda mengurung diri dalam kamar selama berminggu-minggu, menolak untuk mandi dan makan serta tidak mau meninggalkan tempat tidur mereka (Apriliana, Y., 2020). Hal ini mempertegas bahwa sekolah dari rumah dapat memperburuk kesehatan mental. Sedangkan para pelajar dan mahasiswa yang tidak siap dengan new normal melihat bahwa peningkatan kasus di Indonesia yang masih terjadi berpotensi menyebabkan ledakan kasus yang lebih parah lagi. Fasilitas kesehatan yang kurang memadai dan kurangnya kesadaran masyarakat akan pentingnya keselamatan diri dan orang lain juga menjadi alasan mengapa sebaiknya kebijakan yang diambil untuk pembelajaran adalah dengan tatap muka secara daring. Sebagian memilih metode perkuliahan dengan memperpanjang waktu daring, tetapi ada juga yang mengusulkan untuk membuat shift, mengurangi jumlah pelajar dan mahasiswa dalam satu kelas, mengatur tempat duduk, serta protokol kesehatan lainnya yang bisa disesuaikan dengan Keputusan Menteri Kesehatan nomor HK.01.07/MENKES/328/2020 tentang Panduan Pencegahan dan Pengendalian Corona Virus Disease 2019 di Tempat 
Kerja Perkantoran dan Industri dalam Mendukung Keberlangsungan Usaha pada Situasi Pandemi.

Untuk meningkatkan pemahaman dan kesiapan pelajar dan mahasiswa dalam menghadapi masa new normal, maka Departemen maternitas Jurusan Keperawatan Poltekkes Kemenkes Palembang merasa perlu memberikan pemahaman yang utuh kepada pelajar dan mahasiswa dalam menghadapi masa transisi menuju new normal. Solusi yang ditawarkan pada program pengabdian masyarakat ini adalah berupa Edukasi Generasi Z (Digital) dan Pola kehidupan baru menghadapi masa New Normal di Tengah Pandemi Covid-19. Kegiatan pengabdian masyarakat ini dilaksanakan dalam bentuk seminar daring, mengambil bahan kajian tentang kesiapan generasi $\mathrm{Z}$ kembali ke sekolah atau kampus di masa

\section{METODE PELAKSANAAN}

Kegiatan pengabdian masyarakat ini dilaksanakan dalam bentuk seminar secara daring menggunakan fasilitas zoom meeting dan channel youtube oleh tim dosen Depertemen Keperawatan Maternitas Poltekkes Kemenkes Palembang dan 3 orang mahasiswa yang dilibatkan secara penuh. Lokasi kegiatan adalah Kampus Jurusan Keperawatan beralamat di Jalan Merdeka 76-78 Palembang. Pelaksanaan kegiatan tanggal new normal. Kegiatan ini melibatkan siswa maupun mahasiswa di Kota Palembang, dengan harapan dari peserta yang mengikuti seminar daring ini dapat menjembatani penyampaian informasi kepada teman sebaya lainnya, guru, dosen, sekolah maupun kampus yang akan kembali dibuka pada masa new normal.

Target kegiatan pengabdian masyarakat ini adalah : Membentuk pemahaman remaja terkait alasan pemerintah menetapkan kebijakan menuju new normal, Memberikan kesadaran akan pentingnya meningkatkan status hidup sehat, melahirkan pemikir-pemikir masa depan yang peduli terhadap kesehatan dan mempersiapkan diri dengan sebaikbaiknya menghadapi masa new normal dengan menjaga pola kehidupan baru yang lebih sehat.

30 Juli 2020 pukul 14.00 sd 16.00 WIB dengan jumlah peserta 287 orang yang berasal dari perwakilan perguruan tinggi baik yang berdomisili di Palembang maupun di Luar Palembang. Pendekatan yang dilakukan tim dalam menentukan metode yang tepat untuk kegiatan pengaabdian kepada masyarakat ini secara skematis langkah-langkahnya disajikan pada bagan. 1 


\section{PERMASALAHAN MITRA :}

1.Pengetahuan mahasiswa/siswa terkait new normal masih kurang

2.Kekhawatiran yang berlebihan terhadap penularan covid-19

3.Bertambahnya kasus positif covid-19 dari hari kehari

4. Kekhawatiran Munculnya cluster (kampus dan sekolah) bila kebijakan new normal diberlakukan

5.Fasilitas kesehatan yang kurang memadai dan kurangnya kesadaran masyarakat akan pentingnya keselamatan orang lain

6.Persiapan institusi/sekolah menghadapi new normal belum maksimal

\section{METODE PENYELESAIAN :}

1.Edukasi untuk meningkatkan pemahaman mahasiswa/siswa

2.Motivasi untuk membangkitkan semangat dan mengurangi kekhawatiran yang berlebihan karena wabah pandemic covid-19

\section{SOLUSI YANG DITAWARKAN :}

1.Edukasi pengertian New Normal dan kesiapan fisik, psikis dan social yang harus dipersiapkan menghadapi new normal

2.Edukasi Pola Hidup sehat dan segar menghadapi New normal

3.Edukasi untuk tetap menjaga kesehatan reproduksi selama pandemic covid-19 dan menghadapi new normal

4.Edukasi menjaga kesehatan mental selama new Normal

\section{EVALUASI PELAKSANAAN KEGIATAN:}

1.Mengukur efektifitas kegiatan pengabmas

2.Mengukur kesesuaian tema dengan materi yang disampaikan

Berdasarkan bagan 1. Maka langkah pertama kegiatan pengabdian masyarakat ini dimulai dengan melakukan analisis situasi permasalahan mitra dilapangan sehingga diketahui kebutuhan pendidikan/pelatihan, dari sini tim akan mudah menentukan metode yang tepat untuk menyelesaikan permasalahan mitra beserta dengan solusi yang ditawarkan, adapun permasalahan yang Tim Pengabmas temukan dilapangan adalah pengetahuan pelajar dan mahasiswa yang kurang terkait dengan new normal, kekhawatiran yang berlebihan terhadap penularan Covid-19, kekhawatiran munculnya cluster baru (sekolah dan kampus) bila kebijakan new normal di berlakukan, Hal tersebut dibuktikan dengan survei pendahuluan yang dilakukan oleh tim terhadap 40 mahasiswa dimana $21,1 \%$ mengaku bimbang atas diberlakukannya new normal dan 51,5\% tidak siap dan merasa takut menghadapi new normal, disamping itu ketersediaan fasilitas kesehatan baik di ruang publik, sekolah maupun kampus yang masih terbatas serta rendahnya kesadaran masyarakat dalam berperilaku bersih dan sehat akan semakin mempersulit upaya memutus mata rantai penyebaran covid-19. Karena itu solusi yang ditawarkan oleh Tim pengabmas adalah meningkatkan pemahaman masyarakat khususnya pelajar dan mahasiswa berupa edukasi. Edukasi yang diberikan meliputi : Definisi New Normal, Alasan Pemerintah Memberlakukan Kebijakan New Normal, Tetap sehat dan Bugar di Masa New Normal, Menjaga kesehatan mental menghadapi New Normal, Kiat Menjaga fisik, psikis dan social dalam Mempersiapkan New Normal serta 
Menjaga Kesehatan Reproduksi selama pandemic covid-19 dan menghadapati New Normal, dan diakhir pelaksanaan edukasi dilakukan evaluasi untuk mengukur

\section{HASIL dan PEMBAHASAN}

Peserta kegiatan pengabdian kepada masyarakat ini sebagian besar berada di usia 19 tahun $(38,68 \%)$ dengan jenis kelamin terbanyak adalah perempuan (74,56\%). Asal institusi peserta sebagian besar di dominasi dari Poltekkes Kemenkes Palembang yaitu 48,78\%, kemudian diikuti oleh peserta dari efektifitas/manfaat kegiatan pengabdian kepada masyarakat ini dalam meningkatkan pemahaman peserta seminar.

Poltekkes lain di luar Poltekkes Kemenkes Palembang diantaranya Poltekkes Jakarta 3, Poltekkes Medan, Poltekkes Malang, Poltekkes Semarang, Poltekkes Banten, Poltekkes Pangkal Pinang, Poltekkes Padang dan Poltekkes Palangkaraya. Selengkapnya disajikan pada tabel 1 berikut :

Tabel 1. Distribusi Frekuensi Peserta Seminar

\begin{tabular}{lcc}
\hline & \multicolumn{2}{c}{ Jumlah $(\mathrm{n}=287)$} \\
\cline { 2 - 3 } Variabel & $\mathrm{n}$ & $\%$ \\
\hline Usia & 48 & 16,72 \\
18 & 111 & 38,68 \\
19 & 77 & 26,83 \\
20 & 51 & 17,77 \\
21 & & \\
Jenis Kelamin & 214 & 74,56 \\
Perempuan & 73 & 25,44 \\
Laki-laki & & \\
Asal Institusi & 140 & 48,78 \\
Poltekkes Palembang & 43 & 14,98 \\
Poltekkes lainnya & 20 & 6,97 \\
Universitas Bidang Kesehatan & 25 & 8,71 \\
Universitas Non Kesehatan & 41 & 14,29 \\
Sekolah Tinggi Kesehatan & 18 & 6,27 \\
Akademi Kesehatan & 287 & 100 \\
\hline
\end{tabular}

Hasil kegiatan pengabdian kepada masyarakat ini menunjukkan bahwa sebagian besar peserta setelah mengikuti edukasi dalam bentuk seminar daring yaitu $63 \%$ menyatakan sangat puas dengan kedalaman materi yang disampaikan dan sebagian besar peserta menganggap materi yang telah disampaikan sangat bermanfaat yaitu $74 \%$. sebagaimana ditunjukkan pada diagram pie berikut ini : 
Kejelasan Materi

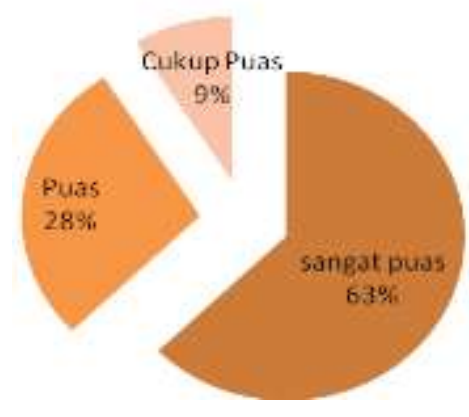

Manfaat Materi

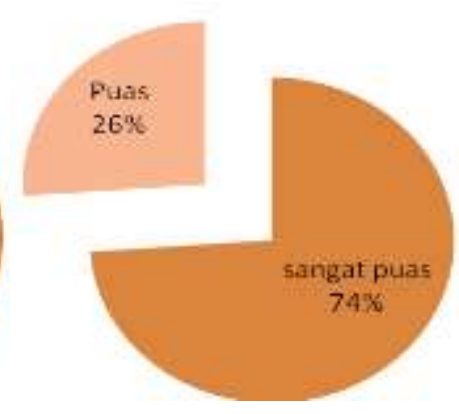

Gambar 2. Tingkat Kepuasan Peserta terhadap materi yang disampaikan

Sebagian besar peserta yaitu $75 \%$ menyatakan siap untuk back to school / back to campus dengan menggunakan protokol kesehatan yang ketat setelah diberi penjelasan dan penguatan menghadapi masa new normal disamping itu karena merasa jenuh dan bosan di rumah, rindu dengan teman dan suasana sekolah atau kampus dan merasa sulit mengerti bila belajar hanya lewat daring saja. Sebagian besar peserta yaitu $81 \%$ bersedia menjadi agen perubahan dengan cara mengajak sebaya baik langsung maupun melalui sosial media yang mereka miliki untuk mematuhi kebijakan yang telah diambil pemerintah sebagai upaya memutus mata rantai penyebaran covid-19 minimal dengan minimal melakukan $3 \mathrm{M}$, yaitu menggunakan masker, mencuci tangan dengan sabun dan air yang mengalir dan menjaga jarak minimal 1 meter.

\section{Kesiapan Back To Campus Komitmen kepada Sebaya}
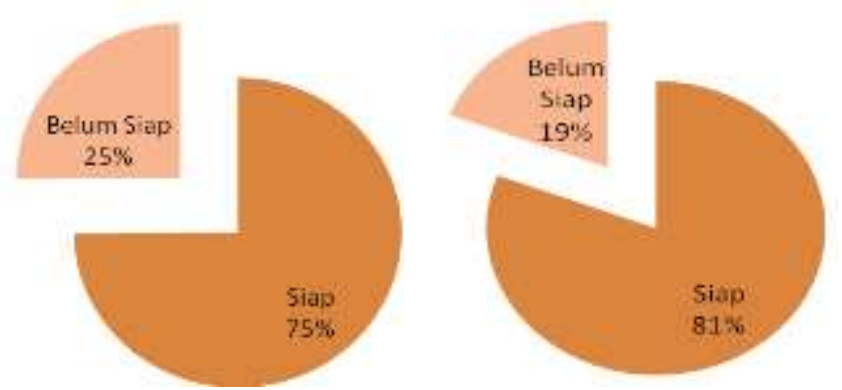

Gambar 3. Kesiapan dan Komintmen Peserta Mendukung Kebijakan Pemerintah menghadapi New Normal

Pendidikan kesehatan merupakan proses perubahan perilaku yang dinamis, bukan hanya proses pemindahan materi dari individu ke orang lain dan bukan seperangkat prosedur yang akan dilaksanakan ataupun hasil yang akan dicapai. Pendidikan kesehatan merupakan proses yang mencakup dimensi dan kegiatan-kegiatan intelektual, psikologi dan sosial yang diperlukan untuk meningkatkan kemampuan individu dalam mengambil keputusan secara sadar dan mempengaruhi kesejahteraan diri, keluarga dan masyarakat (Maulana, 2009). Pendidikan kesehatan merupakan bagian dari keseluruhan upaya kesehatan (promotif, prefentif, kuratif, dan rehabilitatif) yang menitikberatkan pada 
upaya untuk meningkatkan prilaku hidup sehat. Secara konsep pendidikan kesehatan merupakan upaya mempengaruhi/ mengajak orang lain (individu, kelompok dan masyarakat) agar berprilaku hidup sehat. Secara operasional pendidikan kesehatan adalah semua kegiatan untuk memberikan/meningkatkan pengetahuan, sikap dan praktek masyaarakat dalam memelihara dan meningkatkan kesehatannya (Notoatmojo, 2003). Pendidikan kesehatan identik dengan penyuluhan kesehatan karena keduannya berorientasi pada perubahan perilaku yang diharapkan yaitu prilaku sehat, sehingga mempunyai kemampuan mengenal masalah kesehatan dirinya, keluarga dan kelompoknya dalam meningkatkan kesehatannya. Pendidikan kesehatan merupakan bagian dari promosi kesehatan, yaitu suatu proses untuk meningkatkan kemampuan masyarakat dalam memelihara dan meningkatkan kesehatannya dan tidak hanya mengaitkan diri pada peningkatan pengetahuan, sikap dan praktek kesehatan saja, tetapi juga meningkatkan dan memperbaiki lingkungan (baik fisik maupun non fisik) dalam rangka memelihara dan meningkatkan kesehatan mereka (Notoatmodjo, 2007).

Sasaran pendidikan kesehatan pada kegiatan pengabdian pada masyarakat ini menitikberatkan pada remaja yang terdiri dari pelajar dan mahasiswa dengan beberapa pertimbangan;(1) mengingat prosentase usia remaja sebesar $27,94 \%$ dari total penduduk Indonesia dan 66,23\% adalah pelajar dan mahasiswa. Sehingga bila remaja tersebut tidak dipersiapkan secara serius, maka dikhawatirkan akan menjadi penyumbang penyebaran virus Covid-19 paling efektif, mengapa demikian? Hasil penelitian Davies, et.al (2020) menyatakan $81,9 \%$ pasien yang berusia di bawah 20 tahun tidak menunjukkan gejala setelah terinfeksi virus Corona yang dikenal dengan istilah orang tanpa gejala (OTG). Remaja yang OTG ini tidak menyadari kalau mereka telah terinfeksi sehingga mereka bebas melakukan aktivitas seperti biasanya dan sangat berpotensi menularkan orang lain yang berinteraksi langsung dengannya terutama ditempat remaja tersebut tinggal. (2) Remaja adalah kelompok yang paling merasakan dampak akibat pandemi Covid19. Pandemi Covid-19 telah membelenggu kebebasan remaja yang secara karakteristik senang menghabiskan waktu untuk "hangout" dan "nongkrong" bersama teman sebaya dari pada keluarga, Kebijakan PSBB yang diambil pemerintah diikuti penutupan sejumlah fasilitas umum, perkantoran dan sekolah menyebabkan remaja kehilangan beberapa momen besar dalam kehidupannya serta momen seharihari seperti mengobrol dengan teman dan berpartisipasi di kelas atau kampus. Ketidakpastian kapan pandemi Covid-19 ini berakhir menyebabkan dampak psikologis tersendiri bagi remaja seperti merasa cemas, depresi, khawatir yang berlebihan, terisolasi dan kecewa. (3) Remaja dapat dijadikan Agen of Change atau Agen Perubahan dalam melakukan pencegahan penyebaran virus corona dengan memanfaatkan kelebihan remaja sebagai generasi $\mathrm{Z}$ atau generasi digital dimana kelebihan generasi digital adalah aktif dalam bermedia sosial sehingga diharapkan dapat mengajak sebayanya mematuhi protokol kesehatan dan dapat meneruskan konten-konten positif dari pemerintah dalam memutus mata rantai penyebaran Covid-19 dengan cara dan prosedur yang telah ditetapkan oleh pemerintah.

Materi pendidikan kesehatan yang 
disampaikan oleh Tim pengabdian kepada masyarakat dirangkum dalam buku saku dengan judul "Tetap Sehat dan Bugar Di Masa New Normal". New Normal adalah perubahan perilaku untuk tetap menjalankan aktivitas normal namun dengan ditambah penerapan protokol kesehatan guna mencegah penularan Covid-19.
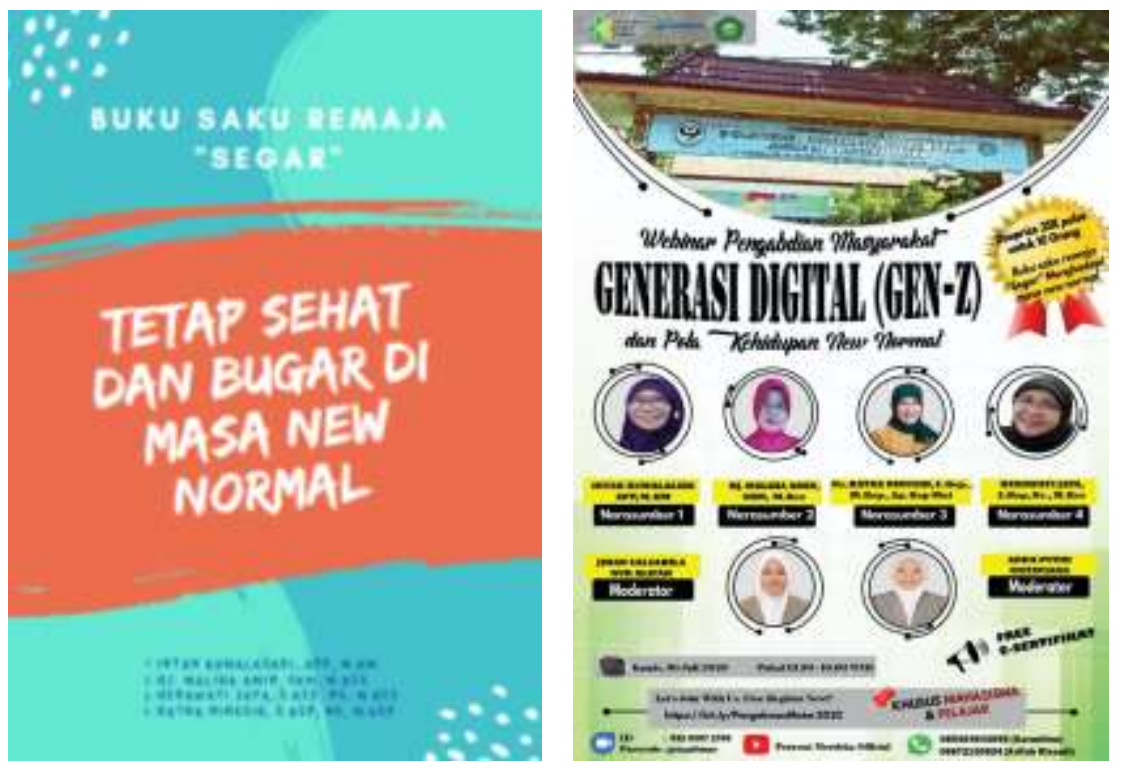

Gambar 4. Buku saku dan Flyer kegiatan pengabmas

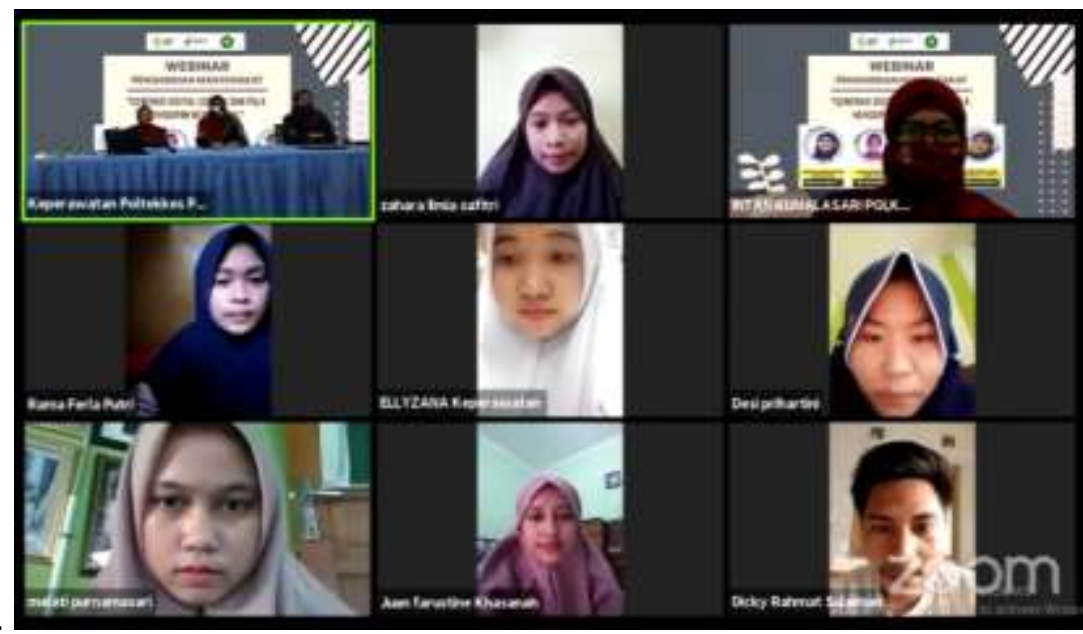

Gambar 5. Kegiatan Pengabmas dalam bentuk seminar daring

Prinsip utama new normal adalah menyesuaikan dengan pola hidup dan standar baru dengan berpedoman pada protokol kesehatan yaitu mencuci tangan, menggunakan masker, menjaga jarak sosial dan mengurangi kontak fisik dengan orang lain, sehingga dengan situasi pandemi remaja masih dapat produktif namun aman dari Covid-19. New Normal adalah sebuah keniscayaan dan harus dipersiapkan, adapun beberapa hal yang dapat dipersiapkan remaja dalam menghadapi era new normal, meliputi persiapan mental, fisik, dan sosial. Persiapan mental berkaitan dengan kesiapan diri secara psikologis agar dapat mencegah diri dari rasa stress karena beradaptasi dengan gaya hidup baru, hal 
ini dapat dilakukan dengan menyadari dan menerima realita bahwa perubahan sedang terjadi dan remaja wajib merespon perubahan itu dengan beradaptasi atau menyesuaikan diri. Sikap menerima dengan keadaan dapat meminimalisir perasaan negatif yang memicu ketidaknyamanan mental. Sebagaimana dilansir laman Psychology Today, "berdamai" serta menerima realita atau kondisi yang baru bisa membawa sesuatu yang dinilai negatif atau mengganggu, dapat menjadi netral atau bahkan positif, jika diterima keberadaannya dan bukan dengan menolaknya. (Nancy, Y., 2020) Remaja Indonesia tidak sendiri, kondisi seperti ini juga dialami oleh remaja di belahan bumi manapun. Selanjutnya berpalinglah sejenak dari menonton, membaca, atau mendengarkan berita dan informasi berlebihan ataupun berita hoax tentang Covid-19 secara berulang-ulang yang dapat membawa pada kecemasan.

Persiapan fisik berkaitan dengan kesiapan diri secara jasmani agar kondisi imunitas tubuh tetap terjaga dan terlindungi dari paparan virus, hal ini dapat dilakukan dengan mengkonsumsi makanan bergizi khususnya yang banyak mengandung vitamin $\mathrm{C}$, minum air putih minimal 8 gelas sehari, istirahat / tidur yang cukup (7-8 jam/hari), rutin berolah raga setiap hari meskipun hanya melakukan aktivitas ringan seperti senam, yoga, latihan nafas dalam dan bermeditasi serta melatih diri agar pola hidup sehat menjadi sebuah gaya hidup ( Anggreni, S., (2020) Latihan apapun akan membantu mengurangi kadar hormon stres tubuh sehingga membantu tubuh dan pikiran menjadi rileks. Latihan fisik juga menghasilkan hormone endorphin (hormone bahagia) yang dapat membantu meningkatkan suasana hati. Bila latihan fisik dilakukan di luar ruangan, maka lakukan sambil menjaga jarak dari orang lain, namun bila dilakukan di dalam rumah, maka dapat membuka jendela agar udara segar dapat masuk.

Persiapan sosial yaitu berkaitan dengan hubungan atau relasi dengan orang lain agar dapat memutus mata rantai penyebaran virus corona, hal ini dapat dilakukan dengan menjaga keamanan saat harus keluar rumah, jaga jarak dan memberi batasan diri, serta sadar akan keselamatan diri dan orang lain. (Anggreni, S., 2020). Kurangi aktivitas tidak perlu di luar rumah, pemberlakuan new normal bukan berarti remaja boleh melakukan aktivitas seperti sediakala sebelum terjadi pandemi karena kerumunan orang akan berisiko menyebabkan penularan virus corona secara masif. Selain itu agar tetap sehat secara sosial, remaja harus tetap terhubung dengan teman, keluarga dan lingkungan sekitarnya. Jalin komunikasi meskipun lewat telepon, whatsapp, instagram telegram, facebook dan media sosial lainnya. Hal tersebut sangat penting dilakukan untuk menghilangkan rasa jenuh dan bosan. Disamping itu melalui akun media sosial yang dimiliki, remaja dapat membantu pemerintah dalam memutus mata rantai penyebaran covid-19 dengan cara mengajak sebayanya untuk mentaati protokol kesehatan, ikut menyebarkan informasi dan pesan-pesan kebaikan terkait upaya pencegahan dan dampak yang ditimbulkan virus corona bila tidak mematuhi aturan yang telah ditetapkan pemerintah.

Keputusan untuk membuka kembali sekolah dan kampus di setiap negara dan wilayah dibuat berdasarkan perhitungan dan penilaian situasi yang cermat dan hatihati serta melibatkan semua pihak 
termasuk pemerintah sebagai pembuat kebijakan (De Buck, E., et.al., 2020). Kebijakan yang dibuat harus melindungi keselamatan dan kesehatan semua orang di komunitas sekolah dan kampus. Oleh karena itu Institusi pendidikan perlu mempersiapkan perangkat dalam menyambut pelajar dan mahasiswa kembali ke sekolah dan kampus diantaranya mempersiapkan fasilitas mencuci tangan yang cukup untuk mencegah antrean panjang, pengecekan suhu sebelum memasuki sekolah dan kampus, memperbanyak poster-poster yang berisi sosialisasi dan himbauan penerapan protocol kesehatan serta informasi pencegahan covid-19 digerbang sekolah, kelas dan lokasi strategis lainnya, menyiapkan perangkat dan model pembelajara baru dengan memperhatikan jumlah siswa, waktu belajar dan pengaturan jarak siswa dalam mengikuti pembelajaran dan durasi belajar di sekolah

\section{KESIMPULAN}

Sebagian besar peserta telah mempersiapkan new normal dengan mengadopsi kebiasaan baru selama pandemi covid-19 ini diantaranya selalu membiasakan diri mencuci tangan sebelum dan sesudah memegang/mengerjakan sesuatu baik dengan air dan sabun ataupun menggunakan hand sanitizer dan membawa handsanitizer sendiri ketika keluar rumah.

Hasil dari kegiatan pengabmas ini dapat dijadikan dasar bagi pihak sekolah/kampus untuk mengintegrasikan slogan-slogan new normal di sekolah/kampus sebagai bagian upaya sekolah/kampus mempersiapkan new normal di kampus dan sekolah dan di evaluasi pelaksanaannya. Pentingnya maupun kampus. Bagi pelajar dan mahasiswa hal-hal yang harus dipersiapkan adalah selalu mencuci tangan sebelum dan setelah memegang sesuatu, menggunakan masker dan membawa masker cadangan, membawa handsanitizer, membawa peralatan/ bekal makanan dari rumah, membawa peralatan ibadah sendiri seperti sarung, mukena dan sajadah, membersihkan meja dan kursi dengan desinfektan sebelum digunakan, menghindari kerumunan, menjaga jarak saat menggunakan kendaraan umum, dan membawa helm pribadi bila berkendaraan umum. Bila semua perangkat telah dipersiapkan dengan baik, segala aturan dan kebijakan telah tersosialisasi dengan baik maka implementasi new normal dilapangan dapat berjalan dengan baik pula sehingga kembali ke sekolah dan ke kampus tidak lagi menjadi sesuatu yang dipersoalkan yang harus di khawatirkan.

memberikan edukasi dan sosialisasi berkesinambungan tentang new normal dengan memberikan pemahaman berulang tentang kebiasaan-kebiasan baru yang harus di adopsi di masa new normal kemudian menyiapkan perangkat PHBS seperti penyediaan tempat cuci tangan dengan air mengalir, pemberlakuan kawasan wajib masker, penggunaan handsanitizer, pengecekan suhu secara berkala, pengaturan jarak serta penyemprotan desinfeksi secara berkala agar kampus new normal dapat terealisasi. Kegiatan ini dapat memberikan manfaat bagi siswa, mahasiswa dan pengelola pendidikan, yaitu meningkatkan pengetahuan dan kesiapan menghadapi new normal. 


\section{DAFTAR PUSTAKA}

Apriliana, Y. (2020). Fakultas Pertanian UGM,

https://news.detik.com/kolom/d-

5047985/new-normal-dalam-

perspektif-mahasiswa (diakses 17

Juli 2020)

BKKBN. 2011. Kajian Profil Penduduk Remaja 10 -24 Tahun : Ada apa dengan Remaja?. Policy Brief Puslitbang Kependudukan-BKKBN.

Seri No.6/Pusdu-BKKBN/Desember 2011.

BPS (2019). Statistik Indonesia 2019. Jakarta. Diunduh pada 23 Juli 2020. Diakses dari https://www.bps.go.id/publication/20 19/07/04/daac1ba18cae1e90706ee58 a/statistik-indonesia-2019.html

Davies, N. G., Klepac P., Liu Y., Prem, K., Jit, M. (2020) Age-dependent effects in the transmission and control of COVID-19 epidemics. Nature Medicine volume 26, pages 1205-

1211 diakses dari https://www.nature.com/articles/s415 91-020-0962-9

De Buck, E., Van Remoortel, H., Dieltjens, T., Verstraeten, H., Clarysse, M., Moens, O., \& Vandekerckhove, P. (2015). Evidence-based educational pathway for the integration of first aid training in school curricula. Resuscitation, $\quad 94, \quad 8-22$. https://doi.org/10.1016/j.resuscitation .2015 .06 .008

The Generation Guide. (2015). Millennials, Gen X, Y, Z and Baby Boomers. Diakses dari http://fourhooks.com/marketing/theg eneration-guide-millennials-gen-x-yz-and-baby-boomers-art5910718593/

Lee, J (2020). Mental health effects of school closures during COVID-19. Lancet Child Adolesc Health. 2020 Jun; 4(6):421. Published online 2020 Apr 14. doi: 10.1016/S2352$\underline{4642(20) 30109-7}$

Kemenkes.go.id, 2020. Pencegahan Covid19 di Tempat Kerja Era New Normal, Jakarta, (diakses 17 Juli 2020)

https://www.kemkes.go.id/article/vie w/20052400003/pencegahan-covid19-di-tempat-kerja-era-newnormal.html

Kemenkes RI. 2020. COVID-19. Infeksi Emerging [serial online]. diakses 5 Juni 2020.. Diunduh dari: https://infeksiemerging.kemkes.go.id.

Kissler S, Tedijanto C, Lipsitch M, dkk. Social distancing strategies for curbing the COVID-19 epidemic. Harvard University's DASH Repository [serial online]. Maret 2020 [diakses 7 Juni 2020].

Maulana, Heri, D.J (2009). Promosi Kesehatan Jakarta : Penerbit Buku Kedokteran EGC,

Nancy, Y. (2020). Tips dari Psikolog dalam Menghadapi New Normal saat Pandemi Corona. https://tirto.id/tipsdari-psikolog-dalam-menghadapinew-normal-saat-pandemi-coronafF41 (diakses 17 Juli 2020) 
Notoatmodjo, Soekidjo (2003). Ilmu-Ilmu Kesehatan Masyarakat (PrinsipPrinsip Dasar) cetakan ke 2 .Jakarta : Rineka Cipta,

Notoatmodjo, Soekidjo, (2007). Promosi Kesehatan dan Ilmu Perilaku Jakarta : Rineka Cipta

Anggreni, S., (2020). Pemerintah tengah mempersiapkan Indonesia memasuki era new normal, namun siapkah remaja menghadapinya? https://www.kisara.or.id/artikel/kesia pan-remaja-menuju-era-newnormal.html (diakses 17 Juli 2020)

Susilo A, Rumende CM, Pitoyo CW, dkk.(2020) Coronavirus Disease 2019: Tinjauan Literatur Terkini. $J$ Penyakit Dalam Indonesia.7:45-77. http://jurnalpenyakitdalam.ui.ac.id/in dex.php/jpdi/article/view/415/228

Surat Keputusan Menteri Kesehatan nomor HK.01.07/MENKES/328/2020

tentang Panduan Pencegahan dan Pengendalian Corona Virus Disease 2019 di Tempat Kerja Perkantoran dan Industri dalam Mendukung Keberlangsungan Usaha pada Situasi Pandemi.

WHO (2020). WHO Director-General's opening remarks at the media briefing on COVID-19 . World Health Organization [serial online]. Diunduh dari: https://www.who.int/dg/speeches/det ail/w ho-director-general-s-openingremarks at-the-media-briefing-oncovid-19---11- march-2020 